\title{
Primary Hyperparathyroidism in Patients with Multiple Endocrine Neoplasia Type 1
}

\author{
Grzegorz Piecha, ${ }^{1}$ Jerzy Chudek, ${ }^{1,2}$ and Andrzej Więcek ${ }^{1}$ \\ ${ }^{1}$ Department of Nephrology, Endocrinology and Metabolic Diseases, Medical University of Silesia, ul. Francuska 20/24, \\ 40-027 Katowice, Poland \\ ${ }^{2}$ Department of Pathophysiology, Medical University of Silesia, ul. Medyków 18, 40-752 Katowice, Poland
}

Correspondence should be addressed to Andrzej Więcek, awiecek@spskm.katowice.pl

Received 3 November 2010; Accepted 13 December 2010

Academic Editor: A. L. Barkan

Copyright ( $) 2010$ Grzegorz Piecha et al. This is an open access article distributed under the Creative Commons Attribution License, which permits unrestricted use, distribution, and reproduction in any medium, provided the original work is properly cited.

Primary hyperparathyroidism may occur as a part of an inherited syndrome in a combination with pancreatic endocrine tumours and/or pituitary adenoma, which is classified as Multiple Endocrine Neoplasia type 1 (MEN-1). This syndrome is caused by a germline mutation in MEN-1 gene encoding a tumour-suppressor protein, menin. Primary hyperparathyroidism is the most frequent clinical presentation of MEN-1, which usually appears in the second decade of life as an asymptomatic hypercalcemia and progresses through the next decades. The most frequent clinical presentation of MEN-1-associated primary hyperparathyroidism is bone demineralisation and recurrent kidney stones rarely followed by chronic kidney disease. The aim of this paper is to present the pathomechanism, screening procedures, diagnosis, and management of primary hyperparathyroidism in the MEN-1 syndrome. It also summarises the recent advances in the pharmacological therapy with a new group of drugs—calcimimetics.

\section{Introduction}

Primary hyperparathyroidism is rarely a part of multiple endocrine neoplasia type 1 (MEN-1) syndrome with familial occurrence. The genetic background of this syndrome offers a unique opportunity to review a pathomechanism of tumourigenesis that may be also operative in some sporadic tumours.

The classic clinical manifestation of MEN-1 is a composition of parathyroid hyperplasia, pancreatic endocrine tumour, and pituitary adenoma [1]. All three tumours, however, do not develop in all affected patients during their life span. Therefore, the contemporary definition of MEN-1 is the coincidence of at least two of the above-mentioned tumours [1]. A diagnosis of familial MEN-1 requires, besides that, a first-degree relative with at least one of the three tumours [1].

In an autopsy series, prevalence of the MEN-1 syndrome was estimated at 2.2 per 1000 in the general population [2], but biochemical surveys suggested lower figures-0.010.175 per $1000[3,4]$. In patients with primary hyperparathyroidism (HPT) approximately $1-5 \%$ is associated with the MEN-1 syndrome $[3,5]$. Combining this data with HPT incidence, the prevalence of MEN-1 can be estimated to be $10-30$ per 100,000 in the general population.

In about $60 \%$ of MEN-1 patients enteropancreatic tumours are found. Most of them are small and nonsecreting. The most common hormonally active ones are insulinomas and gastrinomas. Opposite to parathyroid tumours MEN-1associated gastrinomas are typically multiple, often malignant [6]. Moreover, it is important to stress that other enteropancreatic tumours usually accompany gastrinoma in MEN-1 [7]. Insulinoma is found in 10-30\% of MEN-1 cases with the classic clinical presentation with recurrent neuroglycopenia, mainly in fasting, similar to that of sporadic cases. Other rare enteropancreatic tumours diagnosed in MEN-1 may secrete somatostatin, glucagon, vasoactive intestinal peptide (VIP), growth hormone-releasing factor (GHRH), 
ACTH, or parathyroid hormone-related peptide (PTHrP) [8].

In approximately $30 \%$ of MEN-1 patients prolactinsecreting microadenomas or "nonfunctional" adenomas are found in the pituitary gland $[9,10]$. Tumours secreting growth hormone or ACTH are less frequent, with the signs and symptoms equivalent to those in sporadic cases.

Neuroendocrine tumour (carcinoid), found in about $14 \%$ of MEN-1 cases, originates mainly from the foregut (thymus, bronchus, stomach, pancreas, duodenum) [11], in contrast to sporadic cases originating mainly from midgut [12]. In up to $40 \%$ of MEN-1 cases nonfunctional adrenal cortical enlargement has been found by radiological imaging [13].

The localization of the tumours in the MEN-1 syndrome cannot be explained by the ubiquitous expression pattern of the mutated gene MEN-1 and its encoded protein, menin. The interaction of menin with mixed-lineage leukaemia protein-containing histone methyl transferase (MLL-HMT) complex mediates tissue-selective tumour-suppressing and tumour-promoting effects and may be responsible for the tissue susceptibility to tumourigenesis in MEN-1 [14].

\section{MEN-1 Gene Function}

The MEN-1 gene is $9.8 \mathrm{~kb}$ in 10 exons located on chromosome 11q13 and encodes a 610 -amino acid $67-\mathrm{kDa}$ protein menin [15]. Menin is ubiquitously expressed, located primarily in the nucleus [16] and is able to bind to the DNA independently of the sequence [17]. In meiosis it colocalizes with telomeres [18]. Menin is able to bind directly or indirectly to the proteins regulating transcription, DNA processing, or DNA repair as well as cytoskeleton-associated proteins [19-21].

Although its exact role is not fully understood, menin acts as a tumour suppressor. It is suggested that in cells lacking menin DNA damage is increased [22]. Inactivation of the MEN-1 gene causes cell transition from $G_{0} / G_{1}$ to $S$ phase and increases their proliferation [23]. Consequently, overexpression of menin induces apoptosis. Loss of this protein prevents apoptosis which normally occurs in cells exposed to UV irradiation or TNF- $\alpha$, and exogenous supplementation of menin restores sensitivity to these stimuli [24]. Moreover, in vitro menin overexpression partially suppresses tumour phenotype in neoplastic cell lines supporting its role as a tumour suppressor [25, 26]. Up to now 459 different germline mutations have been reported in the literature and recently summarized [27]. Most of the mutations identified in MEN-1 subjects cause either absence or low availability of menin [28, 29]. A complete loss of menin has been described in tumours from patients with MEN-1 or from mouse models of MEN-1 [30,31].

A "two-hit" hypothesis is applied to describe the development of tumours in MEN-1 [32]. In a germline carrier of the mutated, nonfunctioning allele a tumour develops after local inactivation of the other allele, allowing clonal initiation and promotion. Sporadic tumours may develop in a similar mechanism as the two alleles are subsequently inactivated in a cell line.

In line with this hypothesis in the sporadic cases of parathyroid adenomas $[33,34]$, pancreatic $[35,36]$ and anterior pituitary tumours $[37,38]$, as well as in carcinoids of lung, thymus and stomach [39, 40], lipomas [38], and skin tumours [41] loss of heterozygosity at the menin locus has been described. Mutation of the MEN-1 gene is the most predominant genetic aberration observed in sporadic endocrine tumours. In approximately $20 \%$ of sporadic parathyroid adenoma, gastrinoma, insulinoma, and bronchial carcinoid an MEN-1 mutation can be found $[42,43]$. No correlation between MEN-1 genotype and the tumour phenotype or aggressiveness has been found [44], therefore MEN-1 sequencing is not useful for tumour staging.

\section{Primary Hyperparathyroidism in MEN-1}

Primary hyperparathyroidism (PHPT) is the most prevalent clinical expression in MEN-1 mutation carriers, present in more than $90 \%$ of cases (Table 1). Most frequently multinodular hyperplasia of parathyroid glands is present; however solitary tumours (usually diagnosed as adenomas) have also been observed. Although the defective MEN-1 gene is a tumour suppressor, the parathyroid carcinoma is diagnosed in the smaller proportion of patients than in sporadic primary hyperparathyroidism. Mild hypercalcemia with normal range serum PTH concentration can usually be detected during the second decade of life [45]. Primary hyperparathyroidism is a progressive disease in MEN-1. Typically the MEN-1-associated parathyroid adenomas are diagnosed at the age of about 25 years [46] -in a considerably younger population compared to the sporadic cases, occurring mainly about the fifth decade of life [47].

A point to be mentioned is the high frequency of supernumerary (up to 20\%) and ectopic parathyroid glands, usually localized within the thyroid gland, in the anterior mediastinum and exceptionally in the pericardium in MEN1 patients [48]. Until now there is no evidence of parathyrematosis in MEN-1-associated PHPT.

The main clinical manifestation of MEN-1-associated PHPT is progressing demineralisation [49] and/or recurrent kidney stones $[50,51]$. It was shown that $44 \%$ of patients with uncontrolled MEN-1-associated PHPT had severe osteopenia ( $\mathrm{T}$ score, $<-2.0$ ) by 35 years of age [49]. Recurrent kidney stones are less frequently reported in MEN-1 families $[50,51]$. Unusually MEN-1 patients develop chronic kidney disease in the course of nephrolithiasis, interstitial nephritis and unrelated to the syndrome diabetes as the most frequent cause of chronic kidney disease all over the world $[51,52]$.

\section{Screening for Primary Hyperparathyroidism in MEN-1}

It is recommended that biochemical screening for hyperparathyroidism, as well as for the other tumours, should be performed every 1-3 years in the carriers of MEN-1 
TABLE 1: Tumours associated with MEN-1 and their penetrance.

\begin{tabular}{|c|c|c|}
\hline Localization & Clinical manifestation & Penetrance \\
\hline \multicolumn{3}{|l|}{ Endocrine } \\
\hline Parathyroid & $\begin{array}{l}\text { Primary hyperparathyroidism (bone demineralisation, kidney } \\
\text { stones) }\end{array}$ & $90 \%$ \\
\hline \multicolumn{3}{|l|}{ Enteropancreatic } \\
\hline Gastrinoma & Zollinger-Ellison syndrome (severe peptic ulceration) & $40 \%$ \\
\hline Insulinoma & Recurrent neuroglycopenia & $10 \%$ \\
\hline Nonfunctioning & Late diagnosis (symptoms related to tumor mass) & $20 \%$ \\
\hline Other & WDHA syndrome, diabetes mellitus & $2 \%$ \\
\hline \multicolumn{3}{|l|}{ Pituitary gland } \\
\hline Prolactinoma & $\begin{array}{l}\text { Galactorrhea, menstrual period anomalies, reduced libido, } \\
\text { erectile dysfunction, infertility }\end{array}$ & $20 \%$ \\
\hline Other & Cushing syndrome, pituitary gland insufficiency & $17 \%$ \\
\hline \multicolumn{3}{|l|}{ Adrenal } \\
\hline Nonfunctioning cortex & "Incidentaloma" & $20 \%$ \\
\hline Pheochromocytoma & $\begin{array}{l}\text { Paroxysmal or permanent arterial hypertension, paroxysmal } \\
\text { tachyarrhythmia, diabetes mellitus }\end{array}$ & $<1 \%$ \\
\hline \multicolumn{3}{|c|}{ Foregut neuroendocrine tumours } \\
\hline Gastric & Carcinoid syndrome & $10 \%$ \\
\hline Thymic & Carcinoid syndrome & $2 \%$ \\
\hline Bronchial & Carcinoid syndrome, chronic cough & $2 \%$ \\
\hline \multicolumn{3}{|l|}{ Nonendocrine } \\
\hline Facial angiofibromas & Local symptoms related to tumor mass & $85 \%$ \\
\hline Collagenomas & Local symptoms related to tumor mass & $70 \%$ \\
\hline Lipomas & Local symptoms related to tumor mass & $30 \%$ \\
\hline Leiomyomas & Local symptoms related to tumor mass & $10 \%$ \\
\hline Meningiomas & Intracranial pressure related symptoms & $5 \%$ \\
\hline Ependymomas & Local symptoms related to tumor mass & $1 \%$ \\
\hline
\end{tabular}

mutation. For a long period of time clinical manifestation is mild, and the lack of regular screening may result in the delay of diagnosis and numerous complications [50].

Total serum calcium concentration corrected for albumin level or ionized calcium fraction has been considered the single sufficient screening test for hyperparathyroidism in MEN-1 [53], partly because identifying the earliest stages of parathyroid growth has not been considered essential. Recently, however, increased cardiovascular risk has been observed in patients with mild hyperparathyroidism even in the absence of hypercalcemia [54]. This may argue for inclusion of serum PTH concentration measurement as a screening test as well. Diagnosis of hyperparathyroidism requires levels of PTH inadequately high for the parallel calcium levels. At present different kits for assessment of PTH are available. Second generation of kits, measuring concentrations of the so-called "intact PTH" (iPTH), are in the general usage. These tests assess not only the concentration 1-84-PTH, but also of a truncated PTH fragment which was deprived of the first 1-6 N-terminal amino acids that do not stimulate PTH receptor. Until now superiority of the third generation of PTH kits, measuring only the concentration of "native" 1-84-PTH, has not been proven for diagnosis of primary hyperparathyroidism, at least in patients without chronic kidney disease.

Routine testing for MEN-1 mutation in young patients with primary hyperparathyroidism is not recommended, as these mutations are rare in unselected patients even below 40 years of age [55]. The testing should be considered in patients with additional risk factors such as multiple gland disease, past history, or coexistence of other tumours characteristic for MEN-1, family history of hyperparathyroidism or MEN-1 tumours [56].

\section{Treatment of MEN-1 Associated Hyperparathyroidism}

Total parathyroidectomy and thymectomy with autotransplantation of parathyroid tissue is the therapy of choice for primary hyperparathyroidism in MEN-1 in contrast to single gland-resection in sporadic cases $[57,58]$. The surgery in MEN-1-related hyperparathyroidism (HPT) bears also more difficulties: postoperative hypoparathyroidism and higher rates of recurrent or persistent HPT [57]. Recurrence is usually located in preserved parathyroid 
tissue-either a previously normal gland or a remnant [59]. Subtotal parathyroidectomy or total parathyroidectomy with thymectomy and autotransplantation is associated with fewer recurrences than selective gland excision [60]. The recurrence rate is strongly influenced by proceeding the operation diagnosis of MEN-1, the surgeon's experience, and the possibility to perform an intraoperative histological examination and quick PTH assessment [58]. The main role of intraoperative PTH assessment is to confirm the removal of all the functional parathyroid tissue before parathyroid autotransplantation.

It is not established if the guidelines for the asymptomatic PHPT are applicable for MEN-1-associated PHPT. Some experts advocate early parathyroidectomy to control even mild hyperparathyroidism as uncontrolled disease is associated with a progressive decline of bone mineral density and the increased risk for kidney stones $[61,62]$. In addition Burgess emphasises education of the patient in respect to hyperparathyroidism recurrence and possible reoperations in the years to come [61].

Because malignancies in MEN-1 parathyroid tumours are uncommon, pharmacological treatment is hypothetically feasible. The development of calcimimetics brought a new effective, however expensive, and until now unlicensed therapeutic option for both sporadic and MEN-1-associated PHPT [63, 64]. Thus, such a therapy seems the only option when surgery is not possible or has been ineffective. Cinacalcet therapy is well tolerated by majority, but not all patients. Gastrointestinal side effects experienced by some patients are followed by discontinuation of this therapy [64]. Additionally calcimimetics have been shown to inhibit parathyroid hyperplasia [65] so one may speculate that they could slow the progression of parathyroid tumours in MEN-1.

\section{Conclusion}

The diagnosis of MEN-1-associated primary hyperparathyroidism should be confirmed by genetic testing. Carriers of MEN-1 mutations require regular screening at least in 3-year intervals regardless of the current presence of hyperparathyroidism from the second decade of life. Surgery remains the main method of primary hyperparathyroidism management despite of high recurrence rate and the necessity of repeated procedures. Calcimimetic agents emerge as new therapeutic option if surgery is not possible or has been ineffective.

\section{References}

[1] M. L. Brandi, R. F. Gagel, A. Angeli et al., "Consensus: guidelines for diagnosis and therapy of MEN type 1 and type 2," Journal of Clinical Endocrinology and Metabolism, vol. 86, no. 12, pp. 5658-5671, 2001.

[2] C. C. Berdjis, "Pluriglandular syndrome. II. Multiple endocrine adenomas in man. A report of five cases and a review of literature," Ophthalmologica, vol. 15, pp. 288-311, 1962.

[3] M. L. Brandi, S. J. Marx, G. D. Aurbach, and L. A. Fitzpatrick, "Familial multiple endocrine neoplasia type I: a new look at pathophysiology," Endocrine Reviews, vol. 8, no. 4, pp. 391405, 1987.

[4] H. F. A. Vasen, G. Griffioen, C. J. M. Lips, A. Struyvenberg, and E. A. van Slooten, "Screening of families predisposed to cancer development in The Netherlands," Anticancer Research, vol. 10, no. 2 B, pp. 555-563, 1990.

[5] S. Uchino, S. Noguchi, M. Sato et al., "Screening of the MEN1 gene and discovery of germ-line and somatic mutations in apparently sporadic parathyroid tumors," Cancer Research, vol. 60 , no. 19 , pp. 5553-5557, 2000.

[6] E. A. M. Geerdink, R. B. van der Luijt, and C. J. M. Lips, "Do patients with multiple endocrine neoplasia syndrome type 1 benefit from periodical screening?" European Journal of Endocrinology, vol. 149, no. 6, pp. 577-582, 2003.

[7] J. A. Norton, D. L. Fraker, H. R. Alexander et al., "Surgery to cure the Zollinger-Ellison syndrome," The New England Journal of Medicine, vol. 341, no. 9, pp. 635-644, 1999.

[8] N. Lévy-Bohbot, C. Merle, P. Goudet et al., "Prevalence, characteristics and prognosis of MEN 1-associated glucagonomas, VIPomas, and somatostatinomas: study from the GTE (Groupe des Tumeurs Endocrines) registry," Gastroenterologie Clinique et Biologique, vol. 28, no. 11, pp. 1075-1081, 2004.

[9] K. Yoshimoto and S. Saito, "Clinical characteristics in multiple endocrine neoplasia type 1 in Japan: a review of 106 patients," Nippon Naibunpi Gakkai zasshi, vol. 67, no. 7, pp. 764-774, 1991.

[10] S. Corbetta, A. Pizzocaro, M. Peracchi, P. Beck-Peccoz, G. Faglia, and A. Spada, "Multiple endocrine neoplasia type 1 in patients with recognized pituitary tumours of different types," Clinical Endocrinology, vol. 47, no. 5, pp. 507-512, 1997.

[11] Q. Y. Duh, C. P. Hybarger, R. Geist et al., "Carcinoids associated with multiple endocrine neoplasia syndromes," American Journal of Surgery, vol. 154, no. 1, pp. 142-148, 1987.

[12] J. D. Godwin, "Carcinoid tumors. An analysis of 2837 cases," Cancer, vol. 36, no. 2, pp. 560-569, 1975.

[13] B. Skogseid, C. Larsson, P. G. Lindgren et al., "Clinical and genetic features of adrenocortical lesions in multiple endocrine neoplasia type 1," Journal of Clinical Endocrinology and Metabolism, vol. 75, no. 1, pp. 76-81, 1992.

[14] A. Gracanin, K. M. A. Dreijerink, R. B. van der Luijt, C. J. M. Lips, and J. W. M. Höppener, "Tissue selectivity in multiple endocrine neoplasia type 1-associated tumorigenesis," Cancer Research, vol. 69, no. 16, pp. 6371-6374, 2009.

[15] S. C. Chandrasekharappa, S. C. Guru, P. Manickam et al., "Positional cloning of the gene for multiple endocrine neoplasia-type 1," Science, vol. 276, no. 5311, pp. 404-406, 1997.

[16] S. C. Guru, P. K. Goldsmith, A. L. Burns et al., "Menin, the product of the MEN1 gene, is a nuclear protein," Proceedings of the National Academy of Sciences of the United States of America, vol. 95, no. 4, pp. 1630-1634, 1998.

[17] P. La, A. C. Silva, Z. Hou et al., "Direct binding of DNA by tumor suppressor menin," Journal of Biological Chemistry, vol. 279, no. 47, pp. 49045-49054, 2004.

[18] K. Suphapeetiporn, J. M. Greally, D. Walpita, T. Ashley, and A. E. Bale, "MEN1 tumor-suppressor protein localizes to telomeres during meiosis," Genes Chromosomes and Cancer, vol. 35, no. 1, pp. 81-85, 2002.

[19] S. K. Agarwal, S. C. Guru, C. Heppner et al., "Menin interacts with the AP1 transcription factor JunD and represses JunDactivated transcription," Cell, vol. 96, no. 1, pp. 143-152, 1999.

[20] A. Poisson, B. Zablewska, and P. Gaudray, "Menin interacting proteins as clues toward the understanding of multiple 
endocrine neoplasia type 1," Cancer Letters, vol. 189, no. 1, pp. $1-10,2003$.

[21] K. E. Sukhodolets, A. B. Hickman, S. K. Agarwal et al., "The 32-kilodalton subunit of replication protein A interacts with menin, the product of the MEN1 tumor suppressor gene," Molecular and Cellular Biology, vol. 23, no. 2, pp. 493-509, 2003.

[22] A. Sakurai, M. Katai, Y. Itakura, Y. Ikeo, and K. Hashizume, "Premature centromere division in patients with multiple endocrine neoplasia type 1," Cancer Genetics and Cytogenetics, vol. 109, no. 2, pp. 138-140, 1999.

[23] R. W. Schnepp, Y. X. Chen, H. Wang et al., "Mutation of tumor suppressor gene Men1 acutely enhances proliferation of pancreatic islet cells," Cancer Research, vol. 66, no. 11, pp. 5707-5715, 2006.

[24] R. W. Schnepp, H. Mao, S. M. Sykes et al., "Menin induces apoptosis in murine embryonic fibroblasts," Journal of Biological Chemistry, vol. 279, no. 11, pp. 10685-10691, 2004.

[25] Y. S. Kim, A. L. Burns, P. K. Goldsmith et al., "Stable overexpression of MEN1 suppresses tumorigenicity of RAS," Oncogene, vol. 18, no. 43, pp. 5936-5942, 1999.

[26] P. Stålberg, P. Grimfjärd, M. Santesson et al., "Transfection of the multiple endocrine neoplasia type 1 gene to a human endocrine pancreatic tumor cell line inhibits cell growth and affects expression of JunD, $\delta$-like protein 1 /preadipocyte factor-1, proliferating cell nuclear antigen, and QM/Jif-1," Journal of Clinical Endocrinology and Metabolism, vol. 89, no. 5, pp. 2326-2337, 2004.

[27] M. C. Lemos and R. V. Thakker, "Multiple endocrine neoplasia type 1 (MEN1): analysis of 1336 mutations reported in the first decade following identification of the gene," Human Mutation, vol. 29, no. 1, pp. 22-32, 2008.

[28] S. J. Marx, S. K. Agarwal, M. B. Kester et al., "Germline and somatic mutation of the gene for multiple endocrine neoplasia type 1 (MEN1)," Journal of Internal Medicine, vol. 243, no. 6, pp. 447-453, 1998.

[29] S. J. Marx, S. K. Agarwal, M. B. Rester et al., "Multiple endocrine neoplasia type 1: clinical and genetic features of the hereditary endocrine neoplasias," Recent Progress in Hormone Research, vol. 54, pp. 397-439, 1999.

[30] J. S. Crabtree, P. C. Scacheri, J. M. Ward et al., "A mouse model of multiple endocrine neoplasia, type 1, develops multiple endocrine tumors," Proceedings of the National Academy of Sciences of the United States of America, vol. 98, no. 3, pp. 1118$1123,2001$.

[31] J. S. Crabtree, P. C. Scacheri, J. M. Ward et al., "Of mice and MEN1: insulinomas in a conditional mouse knockout," Molecular and Cellular Biology, vol. 23, no. 17, pp. 6075-6085, 2003.

[32] A. G. Knudson Jr., "Mutation and cancer: statistical study of retinoblastoma," Proceedings of the National Academy of Sciences of the United States of America, vol. 68, no. 4, pp. 820823, 1971.

[33] H. Tahara, A. P. Smith, R. D. Gaz, V. L. Cryns, and A. Arnold, "Genomic localization of novel candidate tumor suppressor gene loci in human parathyroid adenomas," Cancer Research, vol. 56, no. 3, pp. 599-605, 1996.

[34] F. Farnebo, B. T. Teh, C. Dotzenrath et al., "Differential loss of heterozygosity in familial, sporadic, and uremic hyperparathyroidism," Human Genetics, vol. 99, no. 3, pp. 342-349, 1997.

[35] B. T. Teh, N. K. Hayward, S. Wilkinson, G. M. Woods, D. Cameron, and J. J. Shepherd, "Clonal loss of INT-2 alleles in sporadic and familial pancreatic endocrine tumours," British Journal of Cancer, vol. 62, no. 2, pp. 253-254, 1990.
[36] L. V. Debelenko, Z. Zhuang, M. R. Emmert-Buck et al., "Allelic deletions on chromosome $11 \mathrm{q} 13$ in multiple endocrine neoplasia type 1-associated and sporadic gastrinomas and pancreatic endocrine tumors," Cancer Research, vol. 57, no. 11, pp. 2238-2243, 1997.

[37] A. S. Bates, W. E. Farrell, E. J. Bicknell et al., "Allelic deletion in pituitary adenomas reflects aggressive biological activity and has potential value as a prognostic marker," Journal of Clinical Endocrinology and Metabolism, vol. 82, no. 3, pp. 818-824, 1997.

[38] Q. Dong, L. V. Debelenko, S. C. Chandrasekharappa et al., "Loss of heterozygosity at 11q13: analysis of pituitary tumors, lung carcinoids, lipomas, and other uncommon tumors in subjects with familial multiple endocrine neoplasia type 1," Journal of Clinical Endocrinology and Metabolism, vol. 82, no. 5, pp. 1416-1420, 1997.

[39] O. Jakobovitz, D. Nass, L. DeMarco et al., "Carcinoid tumors frequently display genetic abnormalities involving chromosome 11," Journal of Clinical Endocrinology and Metabolism, vol. 81, no. 9, pp. 3164-3167, 1996.

[40] L. V. Debelenko, M. R. Emmert-Buck, Z. Zhuang et al., "The multiple endocrine neoplasia type I gene locus is involved in the pathogenesis of type II gastric carcinoids," Gastroenterology, vol. 113, no. 3, pp. 773-781, 1997.

[41] S. Pack, M. L. Turner, Z. Zhuang et al., "Cutaneous tumors in patients with multiple endocrine neoplasia type 1 show allelic deletion of the MEN1 gene," Journal of Investigative Dermatology, vol. 110, no. 4, pp. 438-440, 1998.

[42] C. Heppner, M. B. Kester, S. K. Agarwal et al., "Somatic mutation of the MEN1 gene in parathyroid tumours," Nature Genetics, vol. 16, no. 4, pp. 375-378, 1997.

[43] Z. Zhuang, A. O. Vortmeyer, S. Pack et al., "Somatic mutations of the MEN1 tumor suppressor gene in sporadic gastrinomas and insulinomas," Cancer Research, vol. 57, no. 21, pp. 46824686, 1997.

[44] S. U. Goebel, C. Heppner, A. L. Burns et al., "Genotype/phenotype correlation of multiple endocrine neoplasia type 1 gene mutations in sporadic gastrinomas," Journal of Clinical Endocrinology and Metabolism, vol. 85, no. 1, pp. 116123, 2000.

[45] J. R. Burgess, T. M. Greenaway, and J. J. Shepherd, "Expression of the MEN-1 gene in a large kindred with multiple endocrine neoplasia type 1," Journal of Internal Medicine, vol. 243, no. 6, pp. 465-470, 1998.

[46] D. Trump, B. Farren, C. Wooding et al., "Clinical studies of multiple endocrine neoplasia type 1 (MEN1)," QJM, vol. 89, no. 9, pp. 653-669, 1996.

[47] H. Heath, S. F. Hodgson, and M. A. Kennedy, "Primary hyperparathyroidism. Incidence, morbidity, and potential economic impact in a community," The New England Journal of Medicine, vol. 302, no. 4, pp. 189-193, 1980.

[48] M. H. Kivlen, D. L. Bartlett, S. K. Libutti et al., "Reoperation for hyperparathyroidism in multiple endocrine neoplasia type 1," Surgery, vol. 130, no. 6, pp. 991-998, 2001.

[49] J. R. Burgess, R. David, T. M. Greenaway, V. Parameswaran, and J. J. Shepherd, "Osteoporosis in multiple endocrine neoplasia type 1 . Severity, clinical significance, relationship to primary hyperparathyroidism, and response to parathyroidectomy," Archives of Surgery, vol. 134, no. 10, pp. 1119-1123, 1999.

[50] J. Chudek, G. Piecha, T. Nieszporek, F. Marini, M. L. Brandi, and A. Wiecek, "Novel 1113delC menin gene mutation in a Polish family with multiple endocrine neoplasia type 1 
syndrome," European Journal of Internal Medicine, vol. 17, no. 6, pp. 447-449, 2006.

[51] C. Molino, F. Fabbian, G. Russo et al., "MEN type 1 and chronic renal failure: a rarely reported associationMEN tipo 1 ed insufficienza renale: una associazione poco conosciuta," Giornale Italiano di Nefrologia, vol. 24, no. 1, pp. 79-82, 2007.

[52] A. Satoh and T. Iigaya, "Multiple endocrine neoplasia type 1 with pyonephrosis," International Journal of Urology, vol. 9, no. 7, pp. 402-404, 2002.

[53] L. Benson, S. Ljunghall, G. Akerstrom, and K. Oberg, "Hyperparathyroidism presenting as the first lesion in multiple endocrine neoplasia type 1," American Journal of Medicine, vol. 82, no. 4, pp. 731-737, 1987.

[54] E. Hagström, E. Lundgren, J. Rastad, and P. Hellman, "Metabolic abnormalities in patients with normocalcemic hyperparathyroidism detected at a population-based screening," European Journal of Endocrinology, vol. 155, no. 1, pp. 33-39, 2006.

[55] A. Skandarajah, A. Barlier, N. Morlet-Barlat et al., "Should routine analysis of the MEN1 gene be performed in all patients with primary hyperparathyroidism under 40 years of age?" World Journal of Surgery, vol. 34, no. 6, pp. 1294-1298, 2010.

[56] M. Kihara, A. Miyauchi, Y. Ito et al., "MEN1 gene analysis in patients with primary hyperparathyroidism: 10-year experience of a single institution for thyroid and parathyroid care in Japan," Endocrine Journal, vol. 56, no. 5, pp. 649-656, 2009.

[57] S. J. Marx, "Multiple endocrine neoplasia type 1," in The Parathyroids, J. P. Bilezikian, R. Marcus, and M. A. Levine, Eds., pp. 535-584, Academic Press, New York, NY, USA, 2001.

[58] F. Tonelli, T. Marcucci, F. Giudici, A. Falchetti, and M. L. Brandi, "Surgical approach in hereditary hyperparathyroidism," Endocrine Journal, vol. 56, no. 7, pp. 827-841, 2009.

[59] M. D. B. Salmeron, J. M. R. Gonzalez, J. S. Fornos et al., "Causes and treatment of recurrent hyperparathyroidism after subtotal parathyroidectomy in the presence of multiple endocrine neoplasia 1," World Journal of Surgery, vol. 34, no. 6, pp. 1325-1331, 2010.

[60] J. Waldmann, C. L. López, P. Langer, M. Rothmund, and D. K. Bartsch, "Surgery for multiple endocrine neoplasia type 1-associated primary hyperparathyroidism," British Journal of Surgery, vol. 97, no. 10, pp. 1528-1534, 2010.

[61] J. Burgess, "How should the patient with multiple endocrine neoplasia type 1 (MEN 1) be followed?" Clinical Endocrinology, vol. 72, no. 1, pp. 13-16, 2010.

[62] J. A. Norton, D. J. Venzon, M. J. Berna et al., "Prospective study of surgery for primary hyperparathyroidism (HPT) in multiple endocrine neoplasia-type 1 and Zollinger-Ellison syndrome: long-term outcome of a more virulent form of HPT," Annals of Surgery, vol. 247, no. 3, pp. 501-510, 2008.

[63] M. Peacock, J. P. Bilezikian, P. S. Klassen, M. D. Guo, S. A. Turner, and D. Shoback, "Cinacalcet hydrochloride maintains long-term normocalcemia in patients with primary hyperparathyroidism," Journal of Clinical Endocrinology and Metabolism, vol. 90, no. 1, pp. 135-141, 2005.

[64] V. J. Moyes, J. P. Monson, S. L. Chew, and S. A. Akker, "Clinical use of cinacalcet in MEN1 hyperparathyroidism," International Journal of Endocrinology, vol. 2010, Article ID 906163, 4 pages, 2010.

[65] M. Wada, Y. Furuya, J. I. Sakiyama et al., "The calcimimetic compound NPS R-568 suppresses parathyroid cell proliferation in rats with renal insufficiency: control of parathyroid cell growth via a calcium receptor," Journal of Clinical Investigation, vol. 100, no. 12, pp. 2977-2983, 1997. 


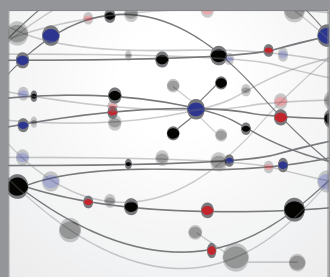

The Scientific World Journal
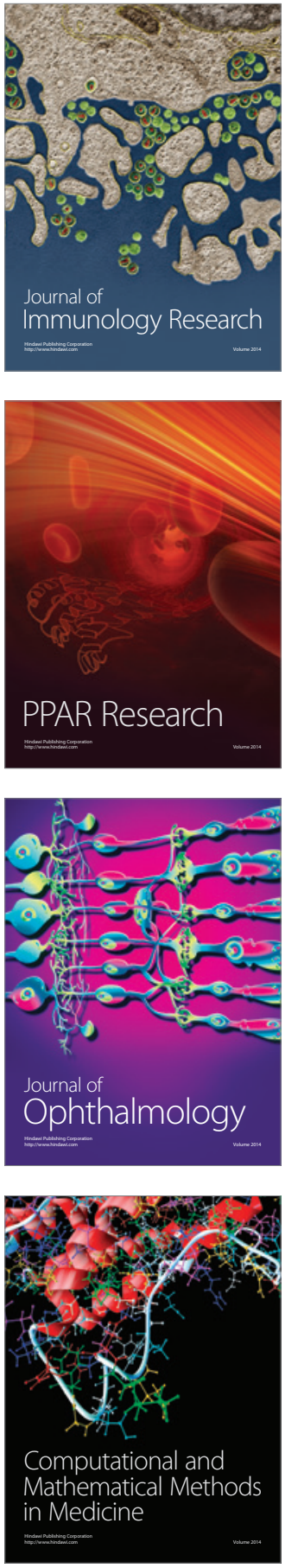

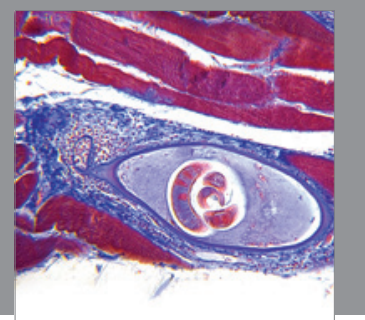

Gastroenterology

Research and Practice
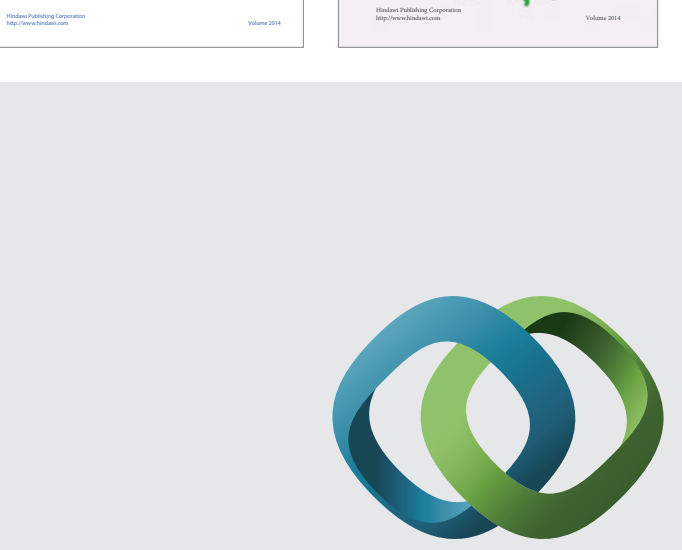

\section{Hindawi}

Submit your manuscripts at

http://www.hindawi.com
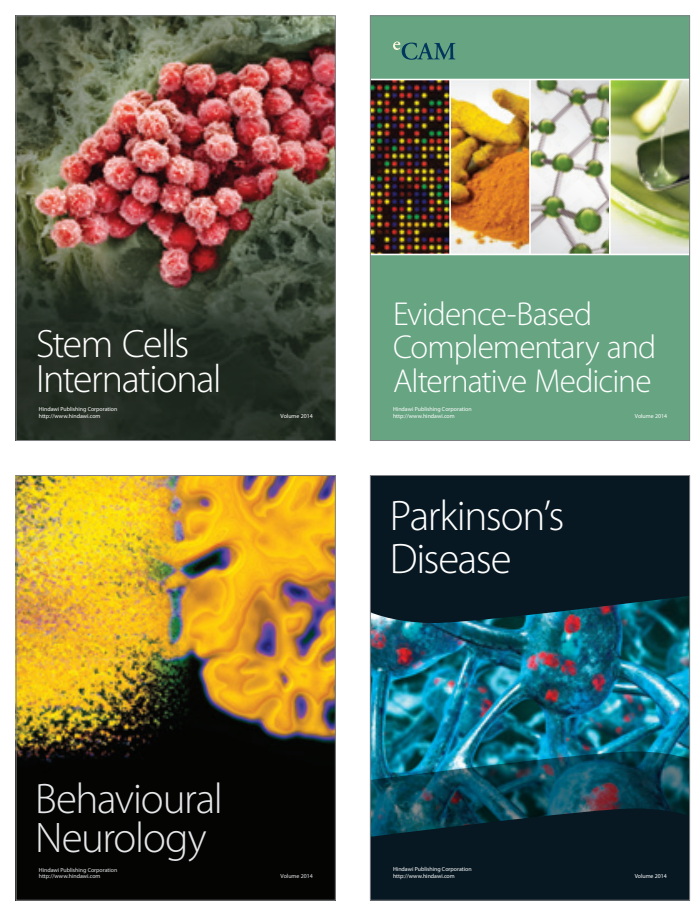

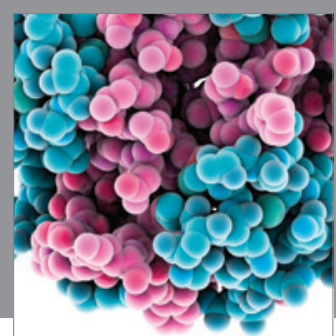

Journal of
Diabetes Research

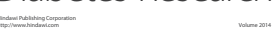

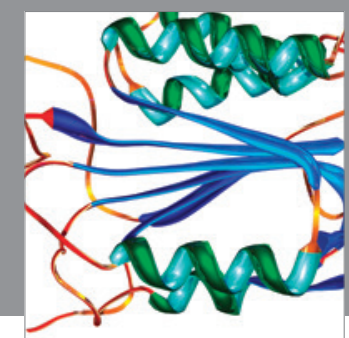

Disease Markers
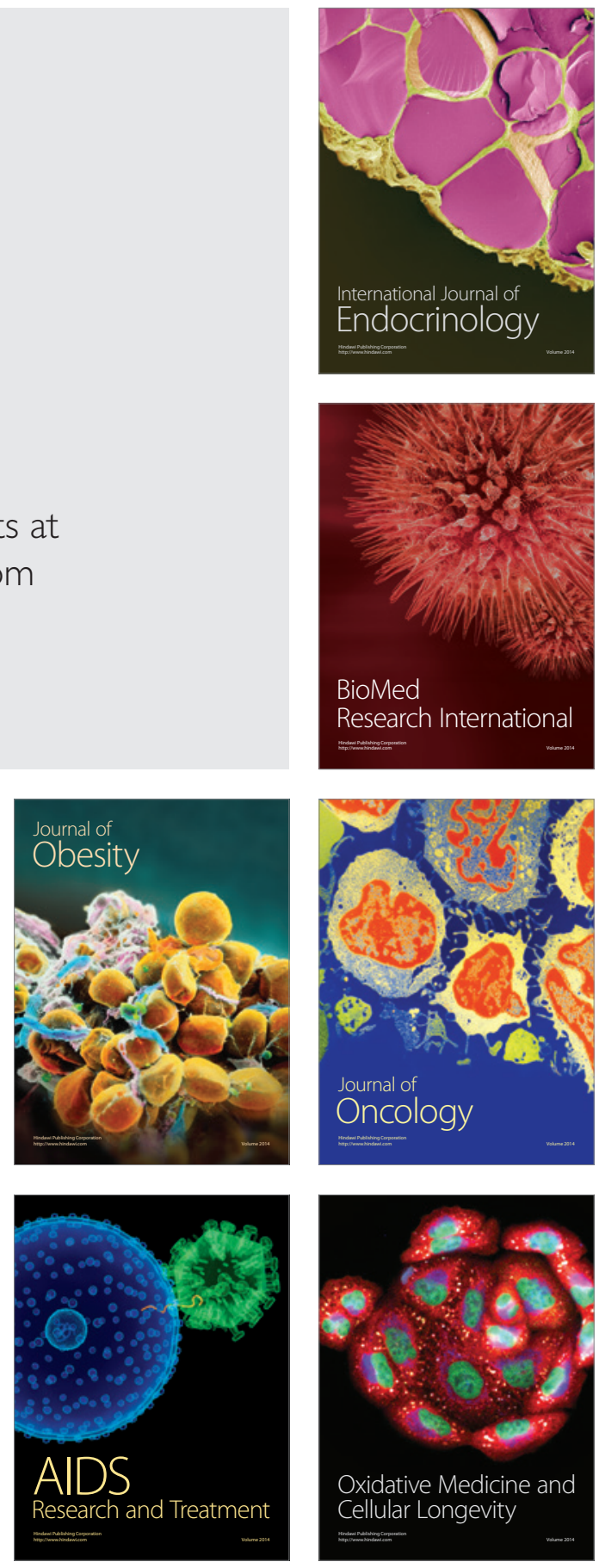